DOI 10.31558/2518-7953.2019.1.14

УДК 342.9

\author{
О. П. Письменна \\ доцент кафедри теорії та історії \\ держави і права та адміністративного права \\ Донецького національного університету \\ імені Василя Стуса, \\ канд. юрид. наук, доцент
}

\title{
ЩОДО ПРАВОВОЇ ОСНОВИ ФУНКЦІОНУВАННЯ НАЦІОНАЛЬНОЇ ПОЛІЦІЇ УКРАЇНИ
}

Ключові слова: Наџчіональна поліччія, підрозділи, дисцчиплінарна відповідальність, поліцейський, принц̧ипи, робота з кадрами.

Одним із новітніх напрямів розбудови демократичної, правової, соціальної держави є курс на трансформацію правоохоронних органів України, зокрема Національної поліції, в органи правопорядку європейського зразка. Так, 2 липня 2015 року було прийнято Закон України «Про Національну поліцію», що визначає правові засади організації та діяльності Національної поліції України, статус поліцейських, а також порядок проходження служби в Національній поліції України. Проте неможливо остаточно стверджувати, що робота поліції є дієвою та цілковито регламентованою на законодавчому рівні. Нормативно-правова база, якою керуються поліцейські у своїй роботі, на жаль, є недосконалою. Підзаконні акти, що регулюють роботу таких територіальних органів поліції як Департамент захисту економіки, Департамент кіберполіції, Департамент протидії наркозлочинності, Департамент внутрішньої безпеки хоч і були прийняті, однак, досі не оприлюднені. Відсутній вичерпний перелік підстав притягнення поліцейського до дисциплінарної відповідальності, неповністю визначено сукупність принципів діяльності поліцейських. І це невичерпний перелік аспектів, які потребують вирішення.

Основою дослідження обраної теми слугували праці таких вчених як О. В. Когут, М. І. Логвиненко, А. В. Солонар, В. А. Глуховеря, Д. С. Денисюк та інші. Враховуючи той факт, що трансформація Національної поліції України досі триває, наукового доробку для удосконалення правового забезпечення функціонування системи поліції недостатньо.

Наведене вище вказує на актуальність теми изієі статті та доцільність ї̈ подальшого дослідження з метою обгрунтування пропозищій щуодо удосконалення правової основи функціонування Наџіональної поліиії України.

У ст. 1 Закону України «Про Національну поліцію» від 2 липня 2015 року (далі - Закон про поліцію) зазначено, що Національна поліція України (поліція) - 
це центральний орган виконавчої влади, який служить суспільству шляхом забезпечення охорони прав і свобод людини, протидії злочинності, підтримання публічної безпеки і порядку [1]. У ч. 2 ст. 21 Закону про поліцію передбачено, що керівник поліції призначається на посаду та звільняється з посади Кабінетом Міністрів України за поданням Прем'єр-міністра України відповідно до пропозицій Міністра внутрішніх справ. Проте, як вже зазначалося, Національна поліція є центральним органом виконавчої влади. Відтак, наведена норма суперечить ч. 1 ст. 19 Закону України «Про центральні органи виконавчої влади» від 17 березня 2011 року, де вказано, що керівник центрального органу виконавчої влади призначається на посаду та звільняється з посади Кабінетом Міністрів України за пропозицією Комісії з питань вищого корпусу державної служби. Комісія з питань вищого корпусу державної служби вносить на розгляд Кабінету Міністрів України пропозиції щодо кандидатури для призначення на посаду керівника центрального органу виконавчої влади за результатами конкурсу відповідно до законодавства про державну службу [2].

Враховуючи наявність зазначеної колізії, пропонується внести уточнення до ст. 1 Закону про поліцію, виклавши іiі у такій редакції: «Національна поліція України (поліція) - це центральний орган виконавчої влади зі сnеціальним сmaтусом, який служить суспільству шляхом забезпечення охорони прав і свобод людини, протидії злочинності, підтримання публічної безпеки і порядку». Відповідно до таких змін на Національну поліцію поширюватиметься дія ст. 24 Закону України «Про центральні органи виконавчої влади», у якій передбачено, що положення цього Закону поширюються на центральні органи виконавчої влади зі спеціальним статусом, крім випадків, коли Конституцією та законами України визначені інші особливості організації та порядку їх діяльності. Тоді передбачений в ч. 2 ст. 21 Закону про поліцію порядок призначення та звільнення 3 посади керівника поліції не суперечитиме ч. 1 ст. 19 Закону України «Про центральні органи виконавчої влади».

Не можна оминути увагою ще один вагомий аспект у функціонуванні поліціï, а саме створення таких міжрегіональних територіальних органів як Департамент захисту економіки [3], Департамент кіберполіції [4], Департамент протидії наркозлочинності [5], Департамент внутрішньої безпеки [6]. Однак, проблему створює неоприлюднення для загального ознайомлення наказів, що регулюють діяльність цих органів. Так, наприклад, Департамент захисту економіки нібито підгрунтям своєї компетенції має Положення про Департамент захисту економіки Національної поліції України, затверджене наказом Голови Національної поліції України від 07.11.2015 року № 81, текст якого наразі не оприлюднено.

Вищевказана проблема стосується і Департаменту кадрового забезпечення. Так, досліджуючи питання функціонування Національної поліції України, вчені 
звертають увагу на необхідність формування професійного корпусу поліцейських як шлях до підвищення рівня довіри громадян до Національної поліції, здатного дійсно стояти на захисті прав та основоположних свобод людини і громадянина, формуючи при цьому і громадянське суспільство, і правову та соціальну державу. На основі цього питання організації кадрового забезпечення Національної поліції на сучасному етапі iї реформування відіграє ключову роль з точки зору ефективності, дієвості поліції як головного інституту держави, що стоїть на сторожі «захисту суспільства шляхом забезпечення охорони прав і свобод людини, протидії злочинності, підтримання публічної безпеки і порядку» [7, с. 135]. Як влучно у цьому випадку зазначає Д. С. Денисюк, кадрова робота - це врегульована нормами адміністративно-процесуального права систематична цілеспрямована діяльність спеціально уповноважених підрозділів (посадових осіб) щодо реалізації кадрової політики із прогнозування та планування, добору, розстановки кадрів, підвищення їхньої кваліфікації та кар'єрного росту, а також оцінювання якості службової діяльності працівників органів внутрішніх справ України [8, с. 130].

Разом $з$ тим при вивченні робіт науковців щодо кадрової діяльності в органах поліції, в тому числі і діяльності Департаменту кадрового забезпечення, постає питання оприлюднення нормативно-правових актів, якими цей Департамент керується при виконанні своїх повноважень Так, наприклад, М. І. Логвиненко та О. С. Дем'яненко, досліджуючи роль та значення роботи з кадрами пропонують прийняти Положення про Департамент кадрового забезпечення Національної поліції України, оскільки вважають, що такий підзаконний акт відсутній, а без належного врегулювання діяльності самого уповноваженого органу складно говорити про результати його діяльності та ефективності [7, с. 136]. Натомість С. Шатрава, аналізуючи стан правового регулювання кадрового забезпечення органів поліції, посилається на наказ Національної поліції від 12.12.2015 р. № 136 «Про затвердження Положення про Департамент кадрового забезпечення Національної поліції України» й виокремлює його основні завдання та функції [9, с. 85].

Наразі текст зазначеного наказу доступний для ознайомлення громадськості лише на неофіційних Інтернет-ресурсах і не у повному обсязі.

Тому, враховуючи, що органи Національної поліції повинні здійснювати свою діяльність на основі принципу відкритості та прозорості, а ч. 5 ст. 9 Закону про поліцію передбачає, що нормативно-правові акти, що регламентують діяльність поліції, обов'язково оприлюднюються на веб-порталі центрального органу управління поліції, вважається необхідним забезпечити виконання цих вимогоприлюднити вищевказані положення для ознайомлення громадськості.

Для удосконалення роботи поліції деякі вчені схиляються до думки щодо необхідності підготовки сучасного Поліцейського кодексу України. На думку фахівців, це є важливою креативною законодавчою ініціативною подією, новацією 
й історичною віхою, оскільки особливістю діяльності нової поліції нашої держави має стати гарантування надійного конституційного фундаменту забезпечення безпеки людини, суспільства, держави від реальних загроз, ризиків і небезпек, який конкретно визначений в Конституції України [10, с. 125-126].

Проте дослідження нормативно-правової бази, що регламентує діяльність Національної поліції, не дає підстав погодитись із пропозицією щодо прийняття Поліцейського кодексу. Попри наявність окремих недоліків, Закон про поліцію загалом виступає достатньо дієвим і надійним механізмом впливу поліції на правопорядок і його підтримання. Одночасне ж існування цього Закону і Поліцейського кодексу недоцільне, адже предмет їх правового регулювання не матиме різниці. Тому, підтримуючи думку Д. В. Власенко, згідно з якою в першу чергу необхідно визначити основні потреби суспільства і держави, які потребують надійного, авторитетного та певною мірою жорсткого захисту від протиправних посягань, зниження рівня злочинності [11, с. 150], можна стверджувати, що потреби в прийнятті Поліцейського кодексу наразі немає.

Наступною вагомою проблемою у роботі правоохоронних органів , на яку звертають увагу науковці, $є$ проблема притягнення поліцейських до дисциплінарної відповідальності. Ст. 11 Дисциплінарного статуту Національної поліції передбачає, що за порушення службової дисципліни поліцейські незалежно від займаної посади та спеціального звання несуть дисциплінарну відповідальність згідно 3 цим Статутом [12]. Підставою для притягнення поліцейського до дисциплінарної відповідальності є дисциплінарний проступок (протиправна винна дія чи бездіяльність поліцейського, що полягає в порушенні ним службової дисципліни, невиконанні чи неналежному виконанні обов'язків поліцейського або виходить за їх межі, порушенні обмежень та заборон, визначених законодавством для поліцейських, а також у вчиненні дій, що підривають авторитет поліції), передбачений ст. 12 Дисциплінарного статуту [12]. Як вірно зазначає О. В. Когут, таке визначення не дає підстави говорити про вичерпний перелік дисциплінарних проступків, але ж Конституція України чітко встановлює, що діяння, які є дисциплінарними правопорушеннями, визначаються виключно законами України. Тому доцільно передбачити вичерпний перелік підстав притягнення поліцейських до відповідальності. В іншому разі незрозуміло, яким чином виконати вказівку п. 10 ч. 1 ст. 19 Дисциплінарного статуту Національної поліції України про те, що у висновку за результатами службового розслідування повинна міститись юридична кваліфікація дисциплінарного проступку з посиланням на положення закону [13, с. 248].

Важливим аспектом при реформуванні поліції за європейським зразком також є всебічне та повне гарантування забезпечення прав і свобод людини і грома- 
дянина. У зв’язку із цим було вдосконалено та розширено принципи діяльності правоохоронних органів (поліцейських). Так, в окремому розділі Закону про поліцію передбачені такі принципи: верховенство права, дотримання прав і свобод людини, законність, відкритість та прозорість, політична нейтральність, взаємодія 3 населенням на засадах партнерства, безперервність. Проте незважаючи на такі нововведення, деякі науковці вбачають ці принципи малоефективними. Так, наприклад Д. С. Денисюк, акцентуючи свою увагу на принципі безперервності зазначає, що його нормативна форма викладу могла б бути більш чіткою, адже залишається незрозумілим, чи можливо звертатися до поліцейського за допомогою поза його службою (не під час виконання ним своїх обов’язків); надавати допомогу - це право чи обов’язок поліцейського; чи буде нести поліцейський відповідальність за ненадання допомоги; чи буде поширюватись на поліцейського соціально-правовий захист, якщо він отримає поранення або ушкодження у таких випадках (поза службою) [14, с. 67]. А. В. Солонар пропонує на підставі аналізу законодавства зарубіжних країн доповнити розділ II «Принципи діяльності поліції» новими статтями, в яких закріпити наступні принципи діяльності поліції: 1) толерантності (Німеччина); 2) співмірності (Грузія); 3) здійснення дискреційних повноважень (Грузія); 4) підконтрольності та підзвітності (Франція); 5) міжнародного співробітництва (Угорщина) [15, с. 66]. Тому важливою дією з боку законодавця може стати внесення чітких поправок та доповнень стосовно принципів діяльності поліцейських з урахуванням пропозицій науковців щодо покращення відповідних положень з метою забезпечення публічної безпеки і порядку.

Таким чином, на основі проведеного аналізу правової основи функціонування Національної полічії України можна запропонувати:

1) статтю 1 Закону про полічуію викласти у такій редакції: «Національна полічуія України (полічуія) - цуе цуентральний орган виконавчої влади зі спеціальним статусом, який служить суспільству иляхом забезпечення охорони прав і свобод людини, протидї злочинності, підтримання публічної безпеки і порядку»;

2) оприлюднити положення про такі територіальні органи Національної поліиії, як Департамент захисту економіки, Департамент кіберполіції, Департамент протидї наркозлочинності, Департамент внутрішньої безпеки, а також Департамент кадрового забезпечення Начіональної полічї Украӥни.

Поряд із изим заслуговують підтримки раніше висловлені у науковій літературі пропозищіі щзодо закріплення у Дисциплінарному статуті Національної полічії вичерпного переліку підстав притягнення поліцеейських до відповідальності, а також доповнення розділу II «Принцчипи діяльності поліції» Закону про поліцүію положеннями стосовно таких принципів як толерантність, співмірність, здійснення дискреційних повноважень, підконтрольність та підзвітність, міжнародне співробітництво. 
1. Про Національну поліцію: Закон України від 2 липня 2015 р. № 580-VIII. Вiдомості Верховної Ради України. 2015. № 40-41. Ст. 379.

2. Про центральні органи виконавчої влади: Закон України від 17 березня 2011 р. № 3166-VI. Відомості Верховної Ради України. 2011. № 38. Ст. 385.

3. Про утворення територіального органу Національної поліції: Постанова Кабінету Міністрів України від 13 жовтня 2015 р. № 830. Офічійний вісник Украӥни. 2015. № 84. Ст. 66.

4. Про утворення територіального органу Національної поліції: Постанова Кабінету Міністрів України від 13 жовтня 2015 р. № 831. Офіиійний вісник Украӥни. 2015. № 84. Ст. 66.

5. Про утворення територіального органу Національної поліції: Постанова Кабінету Міністрів України від 28 жовтня 2015 р. № 886. Офіційний вісник Украӥни. 2015. № 90. Ст. 36.

6. Про утворення територіального органу Національної поліції: Постанова Кабінету Міністрів України від 28 жовтня 2015 р. № 887. Офіційний вісник Украӥни. 2015. № 90. Ст. 37.

7. Логвиненко М. І., Дем'яненко О. С. Роль та значення роботи з кадрами в період реформування органів Національної поліції України. Юридичний науковий електронний журнал. 2018. № 2. C. 134-137.

8. Денисюк С. В. Кадрова робота в органах внутрішніх справ України: поняття та процесуально-правовий аспект. Науковий вісник Херсонського державного університету. 2015. № 3. С. 129-131.

9. Шатрава С. Стан та правове регулювання кадрового забезпечення органів Національної поліції на сучасному етапі розвитку. Підприємництво, господарство і право. 2018. № 1. C. 83-87.

10. Біленчук П., Ярмолюк А. Нове Законодавство України про Національну поліцію і поліцейську діяльність. Яким йому бути? Історико-правовий часопис. 2015. № 2(6). С. 123-126.

11. Власенко Д. В. Сучасні проблеми реформування Національної поліції України. Приватне та публічне право. 2017. № 3. С. 148-152.

12. Дисциплінарний статут Національної поліції України: Закон України від 15 березня 2018 р. № 2337-VIII. Відомості Верховної Ради України. 2018. № 29. Ст. 233.

13. Когут О. В. Проблемні питання Закону України «Про Національну поліцію». Університетські наукові записки. 2017. № 63. С. 244-258.

14. Денисюк Д. С. Принципи діяльності Національної поліції України: теорія та практика реалізації. Митна справа. 2015. № 5. С. 63-68.

15. Солонар А. В. Принципи діяльності поліції в Україні та за кордоном. Правові горизонти. 2017. Вип. 4(17). С. 62-67. 